\title{
ARTICLES
}

\section{A LIFESTYLE OF MODERATION, OR WASATIYYAH: THE ISLAMIC PERSPECTIVE}

\author{
Mohammad Hashim Kamali*
}

\begin{abstract}
This article contains a review of the Islamic sources, the Qur'ān and hadīth, and a selection of scholarly opinion, on a variety of themes from eating and drinking, to speech and humour, to religiosity, work and leisure, art and music. The question in all of this is how to make wasațiyyah as a guide to conduct, personal lifestyle and social relations. Another question posed is whether Islam has visualised, if at all, a model personality that integrates the attributes of wasatiyyah.
\end{abstract}

\section{Introduction}

Islam's conception of a moderate lifestyle is inclusive of the physical, moral and spiritual wellbeing of the individual, a subject on which Islamic sources and scholars provide much persuasive information and advice. A balanced lifestyle begins with the physical aspects of daily life and interaction with one's fellow humans and surrounding environment, the quantitative and qualitative aspects of eating, drinking, work, sociability, worship, entertainment and relaxation.

This article begins with a review of contemporary trends in consumer behaviour that has led, inter alia, to rampant obesity across national boundaries and cultures, not all of which is due to personal over-indulgence but involve what one observer termed 'coronary capitalism,' the excesses of food industries, advertisement and marketing operations. The article ends with a set of recommendations.

My review of these developments underlines consumer and capitalist imbalances that stand in sharp contrast with the Islamic advice of moderation. Attention is then drawn to the alarmingly large scale of food wastage in almost all major cities around the world that also affects supply patterns and agriculture in a variety of ways. Much of the available information seems to be focused on the United States and Europe, but the issues certainly have wider implications for almost all countries and regions.

\section{What is Coronary Capitalism?}

Writing under the title "The costly issue of coronary capitalism," Kenneth Rogoff, former chief economist of the International Monetary Fund, commented that "obesity rates are soaring around the entire world, though among the large 
countries, the problem is perhaps more severe in the United States ... roughly one-third of US adults are obese." Rogoff then explored the food industry's link to broader problems with contemporary capitalism, which "has certainly facilitated the worldwide obesity explosion." Obesity affects life expectancy in numerous ways, ranging from cardiovascular diseases to some types of cancer. The costs are borne not only by the individual but also by society through huge budgetary allocations for healthcare systems. Its negative effects on the quality of life are, of course, a separate matter of even greater concern.

Highly processed corn-based food products, with lots of chemical additives, are well-known to be a major driver of weight gain, but also major revenue earners for their multinational manufacturers. Coronary capitalism is "fantastic for the stock market, which includes companies in the food industry. Highly processed food is also good for jobs, including high-end research employment, advertising and healthcare." Along the way, scientists are paid for finding just the right mix of chemicals to make the latest instant food maximally addictive, and advertisers are paid for peddling it. Even in Malaysia, the kind of tantalising exposures, time slots, and vacuous recommendations that KFC, McDonald's and chocolate products and promoters (all high on junk food content) get on television are in near-total disconnect with their nutritional values.

So who could complain? Certainly not the politicians, who get re-elected when jobs are plentiful and stock prices are up - and get donations from food-processing industries. In the US, politicians who dared to talk about the health, environmental or sustainability implications of processed food would in many cases "find themselves starved of campaign funds." With few resources for high quality public television in most countries, children are co-opted by advertisements, including by the food industry. "The pathological regulatorypolitical-economic dynamic that characterises these industries is far broader." But one can certainly begin to strike a healthier balance than the one we have by giving the public far better information across a range of platforms, so that people can make more informed consumption choices and political decisions. ${ }^{3}$

Kisana Kraisintu, a scholar and public intellectual of Thailand wrote: "It is beyond dispute that we are in the midst of a global health crisis." Millions of people around the world, the majority of them living in developing countries are dying because they lack access to life-saving medications for diseases like AIDS, tuberculosis and malaria. Cost is a crucial factor in this crisis. ${ }^{4}$

Two-thirds of the value of medicine produced globally is accounted for by companies in five major countries, namely, the UK, the USA, Japan, Germany and France. Large-volume markets for lower-price medicines exist in the highly competitive markets of China and India. For the period 1985-1999, the lowincome countries' share of medicine production in the world market declined 
from 3.9 per cent to 2.6 per cent, and that of middle-income countries fell from seven per cent to 4.5 per cent. The share of high-income countries increased from 89.1 per cent to 92.2 per cent. $^{5}$

As the economic gap between industrialised and low-income countries widens, so too does the health gap between the rich and the poor. This is particularly evident in relation to AIDS, tuberculosis and malaria epidemics in Africa. "For too long we have accepted the access gap as a fact of life. Twenty eight million people have died from AIDS and, if things stay as they are, the number of such deaths will be close to 100 million by 2020." In 2001, 500,000 persons in highincome countries took antiretroviral (ARV) therapy and fewer than 25,000 died. Contrast this with Sub-Saharan Africa where fewer than 30,000 persons took ARVs and 2.2 million died. "The huge gap in care has been called a crime against humanity and a holocaust of the poor. It certainly brings realisation that we need to put an end to the global apartheid of poverty and health." and manufacture of medicine must be aimed at improving public health and wellbeing, thereby contributing also to economic growth. There should be an alignment of the profitability goals of industry with society's needs of improved access and affordable healthcare. ${ }^{8}$ One of the possibilities of increasing access to ARVs lies in the transfer of technology for domestic production in the target countries. Yet experience so far in this regard is also not encouraging.

\section{Food Wastage}

A report on wasted food revealed that as much as half of the world's food, amounting to a billion tonnes worth, is wasted. Dr Tim Fox, head of energy and environment at the UK-based Institution of Mechanical Engineers reported: "The amount of food wasted and lost around the world is staggering. This is food that could be used to feed the world's growing population - as well as those in hunger today." "The report drew heavily on work carried out over a number of years for the Food and Agriculture Organisation of the UN. It was further revealed that the waste is being caused by poor storage, strict sell-by dates, bulk offers and consumer fussiness. The study also found that up to 30 per cent of vegetables in the UK were not harvested because of their physical appearance. On the consumer behaviour side, it was further added that "half the food bought in Europe and the US ended up in the bin." This also meant unnecessary waste of the land, water and energy resources that were used in the production, processing and distribution of this food. Commenting on this report, Tom Tanner, from the Sustainable Restaurants Association noted: "It is the power of major retailers convenience shopping and supermarkets on everyone's doorstep - you can nip out and buy a readymade meal in two minutes rather than make use of what's in your fridge." ${ }^{10}$ Tanner added that the weight of food equivalent to three double- 
decker buses is thrown away per restaurant per year in the UK - 30 per cent of that is off the consumer's plate.

A Malaysian observer develops a story line over Malaysia's cuisine as follows: A CNN survey has placed Malaysia in seventh place among the world's 50 most flavoursome food locations, much to the displeasure, apparently of some of its neighbours. Thailand and Singapore have claimed that some of the most renowned Malaysian delicacies originated in their respective countries, yet they did not get the placement! Let that be as is. The ugly side of this story is also noted in these words: "As it is, nutritionists are alarmed by the rapidly increasing number of obese Malaysians." And then comes the advice: "what we need to do is to learn to eat in moderation, and not argue over food. Especially not over dishes that are unequivocally Malaysian." 11 Another Malaysian observer and dietician refers to the Confucian advice, which has many followers in presentday Japan, to stop eating when the stomach is 80 per cent full. Again, it is noted that people in countries with high longevity scores eat their smallest meal in the late afternoon and then abstain from eating for the rest of the day. The Malaysian dietician added that adhering to the advice just noted is likely, as studies show, to extend one's life by eight years. ${ }^{12}$ This would appear to be tantamount to the twothirds full advice from the Prophet of Islam as I shall presently review.

\section{Islam's Perspective on Moderate Eating}

The renowned Hanbalī scholar, Ibn Qayyim al-Jawziyyah (d. 1350 CE) observed that excessive consumption and indulgence in eating is one of the major causes of disease. Many types of illnesses originate in excessive eating and drinking, which obstruct the natural pace of digestion, bodily movements and activities. When one is busy eating food in rapid succession, not allowing the body time to digest one lot before devouring more in disregard to what is actually the needed quantity for one to survive and live - the quality of life is adversely affected. The temptation to eat more is even greater with more varieties which means mixing a myriad of types and quantities frequently, and that in turn makes the stomach used to larger portions. The net result of this is that the good effect of food turns into a harmful one, gradually reducing physical fitness and vitality. But when food is taken in moderate quantity and variety, it sustains and benefits the body. Food can be taken firstly to the extent of need (al-hajjah), then to the extent of sufficiency (al-kifäyah), and then to the level of indulgence and excess (alfadlah). This last should be carefully guarded against. ${ }^{13}$

Ibn Qayyim added further that the Prophet, pbuh, ate little, often a few mouthfuls that sustained him without losing his physical vitality and strength. While the Prophet cautioned against indulgence in eating, he also warned against eating and drinking too little, as this too was harmful, even if done with 
noble devotional intentions, such as fasting too frequently and practicing selfabnegation from eating for ascetic reasons. The Prophet thus forbade connected fasting (sawm al-wișall) and said that there was no spiritual reward to be gained by it. Thus according to a hadith: "One who fasts perpetually has not fasted at all," and he repeated this sentence three times. ${ }^{14}$

In a longer hadìth, it is reported by 'Abd Allāh ibn 'Amr ibn al-'Ạs that the Prophet, pbuh, told him: "O 'Abd Allāh! Is it true that you fast in daytime and then also observe night vigil? I said: yes O Messenger of Allah. He then told me: do not do this. You should fast and open it; observe vigil, then sleep. For your body has a right over you ..., and so has your wife who has a right over you." 15 Later it is reported that during the twilight of his life, 'Abd Allāh was weak and was heard saying "I wish I had acted on the Prophet's advice and his concession (rukhșah) earlier."16

Recommendable moderation in eating and drinking implies the following:

One should try to choose one's intake from clean and healthy food (al-țayyibāt), thus avoiding consumption of the forbidden substances, and food that is obtained through unlawful means. This is the clear purport of the Qur'ānic address to all the believers to eat the țayyibāt (al-Baqarah, 2:172; al-Mu'minūn, 23:51). According to the purport of a hadith, a person who leads a life of indulgence in unlawful activities, eating forbidden food, wearing clothes of doubtful permissibility and so on, even though he may be a pious person by his apparent observances of the religious rituals, his prayer and supplication will not earn him any reward. ${ }^{17}$

Commenting on this hadith, one observer stated that anyone who wishes his supplication $\left(d u^{\prime} \bar{a}^{\prime}\right)$ to be granted must observe these instructions and lead a clean lifestyle that is free of indulgences in haramm. ${ }^{18}$

One should not fill one's stomach to capacity. It is a hallmark of piety for one to follow in this regard what the Prophet has practiced himself: the one third rule as stated above; one third for food, one third for drink, and the last one-third for his vitality and ease. This manner of food intake was of great benefit to body and heart. ${ }^{19}$ If one indulges on an odd occasion, there is no blame, provided it does not become a habit, which would then amount to a violation of the Qur'ānic guideline to the believers that they should avail themselves of the enjoyment of eating and drinking but avoid indulgence and excess (isräf), for " $\mathrm{O}$ children of Adam! Wear elegant clothes when you visit the mosque, and eat and drink but do not be wasteful. For Allah loves not the indulgent prodigals - al-musrifin" (al-A'rāf, 7:31).

Fasting from dusk to dawn during Ramadan is a religious obligation of every able-bodied Muslim. Meeting the challenge of completing a month of fasting is a personal triumph that can be a source of great confidence. Fasting is a Qu'rānic 
duty and act of worship, but also an act of physical and spiritual self-discipline that was enjoined on all Prophets and pious people from time immemorial. To fast means to abstain from food and drink, sexual contact, conflict, arguments, and unkind language or acts. The Sharī'ah grants concessions, however, to a traveller who may break the fast and make up for the lost days later after Ramaḍan, as also for menstruating women.

People who are ill or whose condition would make fasting a health risk, including women who are pregnant or nursing, may break fast but need to compensate for it by feeding the poor or donating money to charity. The Prophet, pbuh, taught that while he himself went on fasting for long periods outside of Ramaḍān, other Muslims should not fast more than every other day during other months of the year. The Prophet preferred Mondays and Thursdays for supererogatory fasting, and forbade fasting on the day of Eid that marks the end of Ramadian, and the day of 'Arafah (during the hajj season) and the day of 'Āshürā' (the $10^{\text {th }}$ day of Muharram marking the tragic martyrdom of Husayn, the Prophet's grandson on the event of Karbala at $680 \mathrm{CE}) .{ }^{20}$ Many commentators of the Qur'ann have gone on record to say that avoiding indulgence in one's food intake, especially if this made a regular part and pattern of one's lifestyle is the essence of good health and good medical advice. ${ }^{21}$

At the end of Ramadān, Muslims celebrate ' $\bar{I} d$ al-Fitr, itself an exercise in spirituality and celebration marking the completion of the Ramadān fasting duty. Muslims are required to give the charity of Fitr, consisting of certain quantities of foodstuffs or their monetary equivalent to the poor. Among the social benefits of fasting often noted is that it inculcates a sense of responsibility and heightened awareness of hunger and discomfort faced by the less fortunate. Furthermore, fasting often acts "like a therapeutic programme in controlling and managing anger." 2

At an International Congress on Health and Ramadan, held in Casablanca in 1994, Muslim and non-Muslim researchers noted that fasting did not worsen the patient's health or baseline medical condition. Shahid Athar, M.D., author of Medical Benefits of Ramadan, also underlined the psychological benefits of fasting, and some of its other health benefits, such as the lowering of essential hypertension, and mild to moderate non-insulin diabetes. ${ }^{23}$

Yet on the other side of the equation, many are known to indulge in over-eating at times of breaking fast at the sunset (iftär) and the early morning (sahür) meals, which tends to negate the beneficial effects of fasting. There is a temptation to overeat, and many seem to find comfort in the plausible thought that indulgence will be compensated for by the next day of fasting. Eating irregularities and swings from totally refraining to total indulgence has become a feature, among the vast majority, of the Ramaḍān fasting month. Hospitals often report higher rates of admissions due to eating disorders. Any health benefits gained from 
fasting are consequently nullified and illness sets in.

Meat consumption is far too high almost everywhere, one might say well beyond the limits of moderation, and should be reduced not only as a matter of Islamic advice on moderation but as a general health advice for all concerned. Food specialists and dieticians also give the same advice when reflecting on the health hazards of meat consumption in large quantities, and frequent meat eating indulgence.

Added to the foregoing is also the reminder that mass meat production is responsible for about 20 per cent of the world $\mathrm{CO}_{2}$ emissions. ${ }^{24}$ People's eating habits also relate to their buying habits. People are not careful enough to take time and read labels when buying food in supermarkets to ascertain the amount of processed and junk food sold at 'bargain' prices. Processed food often contains harmful chemicals emanating from careless use of pesticides, fertilisers and preservatives. There is no "mystery to the rise of diseases like diabetes and other [food related] ... disorders in teenagers and children these days. ${ }^{25}$ Farmers, food processing plants, restaurateurs, media, government authorities, individuals and families all play a role, and all have a responsibility, to ascertain, revise and control the consumption of meat in what they grow, produce and offer for public consumption.

Food wastage is yet another aspect of the problem of resource depletion as discussed earlier. Scientists estimate, moreover, that between 30 to 50 per cent of all food produced in the world is wasted at the table and lost in the production process. If this food is saved the number of undernourished and those facing starvation can be drastically reduced. And if one is a vegetarian, one knows that he or she has enriched the Earth, and helped to reduce the threat of a global water crisis. One's decision to go meatless, or minimise meat consumption, also contributes to slowing down a global food shortage and climate change. ${ }^{26}$ This advice stands sound. In my opinion, all of us - Muslim and non-Muslim alike - should encourage a vegetarian diet among themselves and their families. Climate scientists point out that meat production creates greenhouse gasses. It is estimated that livestock account for 51 per cent of greenhouse gasses. While it is for government agencies, farmers and agribusiness players to take care of the larger issues, there are two simple things that individuals can do: 1) To make sure not to waste food or water, and only cook or order what one can eat; 2) One can go vegetarian or at least take vegetarian food a few days a week, and stop eating meat of ruminant animals, or at least reduce eating meat to just a few times in the week. ${ }^{27}$

\section{Moderation in Speech and Humour}

In matters of speech and sociability, the key Shāfi' ì scholar, 'Izz al-Dīn 'Abd al-Salām (d.1262 CE), has highlighted moderation in speech saying that it is highly recommended that a Muslim says that in which there is some benefit, 
either immediate or in future, or speech which helps to prevent corruption and evil. This is the purport, in fact, of several passages in the Qur'ān as follows:

And when you speak, speak with justice (al-An'ām, 6: 152).

O you who believe, be mindful of Allah and speak or say a word in pursuit only of a righteous cause (al-Aḥzāb, 33:70).

And tell my servants to say (only) that which is best (al-Isrā', 17:53).

The Prophet has added his voice to these guidelines when he said in a hadith that "pleasant speech is a form of charity." ${ }^{28}$ To quote two other hadiths to which a reference has already been made:

Whoever believes in God and the Last Day, let him speak when he has something good to say, or else remain silent. ${ }^{29}$

The hallmark of a good Muslim is to remain silent regarding that which is of no concern to him. ${ }^{30}$

Islam's advice of moderation in speech also extends to the tone of voice in which one conveys a message. One should speak in loud voice only to the extent of making himself audible to his audience. There is emphasis on lowering the tone of one's voice in almost all contexts involving devotional matters, recitation of the Qur'ān in supplication and prayer (al-A'rāf, 7:55) simply because: "God the Most High hears supplication even when uttered quietly, in which case, there is no need to say it loud." ${ }^{11}$ The Prophet's Companions were consequently instructed not to raise their voices in the presence of the Prophet. The guideline here was for them to speak in the manner the Prophet spoke himself and not to raise their voices above that of the Prophet (cf. Qur'ān al-Hujurāt, 49:2; Luqmān, 31:19). It goes contrary to the tenor of this guideline to note in some places the uncomfortably high decibels of the call to prayer (adhān) especially in busy residential areas of mixed populations of Muslim and non-Muslim residents, as the present writer has heard in some places in Kuala Lumpur. Adhän should be loud enough to inform but not so loud as to shock or make the neighbourhood uncomfortable with high volume loudspeakers.

This advice of moderation in the tone of one's voice and the length or otherwise of one's speech is similarly extended to teaching and preaching, what 'Izz al-Dīn 'Abd Al-Salām has phrased as "al-iqtisāad fi'l-mawā'iz". The Prophet has been quoted on more than one occasion to have cautioned his Companions against excess in their sermons and in their teachings lest they make them cumbersome to the audience and tax their attention. For when one goes to excess even in these essentially recommendable activities, they fail to make the desired impact on the heart and mind of listeners and may well nullify the anticipated benefit in them. ${ }^{32}$ The audience is also more likely to forget if the sermon is too lengthy. Brevity in 
speech is a sign of wisdom and knowledge of the speaker who knows where to stop before inflicting fatigue on the listeners. Similar instructions in the hadith are found concerning visits to friends and relatives - that these should neither be too frequent nor too sparing. For diminished visitation encourages estrangement (hijrān), and excess in visitation amounts to imposition and boredom (maläl). ${ }^{33}$

Humour is recommended in principle and is deemed to partake in recreation (istirwāh) both for the joker and his audience. The Prophet is known to have had a sense of humour and practiced it in his own interaction, words and action, both with children and adults. It is a condition of a permissible joke, however, that it is clear of lies. Similarly jokes, whether in words or in action, are either forbidden or reprehensible (mahzür, makrüh) if they are tactless and harmful to one's audience or to those who may not be present, or when it involves taking of someone's belonging in the name of a practical joke. According to the instruction of a hadith:

"None of you may take the belongings of your brother, in jest or in earnest." ${ }^{34}$

The hadìth guidelines on humour also proscribe telling a lie even if it be in jest. Thus it is provided that "Faith is not perfect of a believer unless he abandons lying in the jokes he makes and abandons acrimony even if he is truthful." 35

Moderation is recommended in one's love and affection just as it is the case with anger and reprimand. In a hadìth recorded by al-Bukhārī and Muslim, the Prophet spoke in a prohibitive language:

"Do not hate nor envy one another and avoid attacking one another behind your backs. You must act as God's servants and brethren unto each other. It is not permissible for a Muslim to boycott his brother for more than three days." ${ }^{36}$

According to hadith commentators 'do not hate one another' means that "you avoid creating the causes of hatred." In a similar vein, "boycotting one another" in the hadith under review means "stopping to speak to one another." A total break of communication is the beginning of mutual hatred which should not be allowed to continue for long. Muslims are enjoined in several places in hadith to try to eradicate hostility among themselves through reconciliation efforts. It is a great act of merit for a Muslim to bring peace by reconciling two hostile parties, known as "ișlāh dhāt al-bayn". ${ }^{37}$ In his Adab al-Dìn wa'l-Dunya, Abū'l-Ḥasan al-Māwardī (d. $1058 \mathrm{CE}$ ) has quoted the second Caliph 'Umar to the effect that exuberance in the show of affection begets shortcoming (taqsir $i$ ) and comes in the way of a desired state of relations that leaves space for love to grow. Thus said caliph 'Umar: "let not your love become a burden nor your rancour to become destructive (of the prospects of improvement). ${ }^{.38}$ In a hadìth narrated by Abū Hurayrah, the Prophet is reported to have said concerning a husband and wife: 
Let not a believing man allow hatred in himself toward his believing wife. For if he dislikes her for some aspect of her character, he surely likes her for some of her other qualities. ${ }^{39}$

\section{Work and Leisure}

One often comes across media reports of work and study related imbalances among workers, professional classes, executives, and students who drive themselves to exhaustion due to long working hours they impose upon themselves. The pattern is not confined to the industrial West but also found in other countries across the boundaries of geography and culture. Stress is taking its toll on the health and wellbeing of a wide spectrum of the most productive strata of the world populace.

A recent survey by jobstreet.com in Malaysia revealed that almost 70 per cent of employees spend between two and five hours working beyond their official work hours every day, with 63 per cent admitting to not spending enough time with their family. It also found that nearly 54 per cent of the respondents did not get the chance to finish their annual leave entitlement. ${ }^{40}$ The situation had obviously not improved from the previous year when another survey showed that 32 per cent of Malaysian workers worked between nine and eleven hours a day, higher than the global average. Malaysian women were also ranked the sixteenth most stressed in the world. An extreme example was the tragic death recently of a young Indonesian advertising writer after reportedly working 30 hours straight. The story of her death through overwork went viral on social media. ${ }^{41}$

One hardly needs studies and surveys to tell one what the results of everexertion and fatigue are: depression, obesity, heart disease, hair loss, sexual dysfunction - to mention a few. Reports are also seen often of rising suicide rates among youth beset with negative thoughts due to stress, parental pressure, loss of purpose and despair. The perception holds in Malaysia that the longer the hours put in, the more prolific and praiseworthy becomes the employee. Those who choose to leave the office on time often get a suspicious look for not fulfilling what is expected of them.

Australia has performed exceptionally well in measures of wellbeing, as shown by the fact that it ranks among the top countries in the Better Life Index. People in Australia work on average 1,686 hours a year, less than most nations. Most workers are back with their families after 5pm, with those staying back viewed with disapproval by other workers and colleagues. It is not so much up to the employer but the employee himself/herself to pause and make the needed adjustment toward leading a balanced pattern of work and leisure. ${ }^{42}$

Turning to the Islamic sources, one finds clear instructions in the teachings of the Prophet, who went on record to ask the workers to avoid a work regime that 
would drive them into exhaustion: "You are required to work to the extent of your abilities, for God is not impatient unless you yourselves become impatient."

This is an advice evidently of caution to workers to be aware of their own limitations and avoid over-indulgence and fatigue. For this is not what their faith expects of them. The same message is endorsed in another hadith wherein the Prophet instructed the believers to "Refresh your hearts hour by hour (every now and then), for the hearts tend to go blind when they are denied of a (needed) reprieve." 44

Rest and relaxation is just as necessary for the wellbeing of people as is the work itself. Leisure time and vacation should therefore be given due attention in the determination of rules that regulate labour relations. This is also the purport of the hadith in which the Prophet has reportedly said: "Your body has a right over you," and one of those rights is to avail it of rest and relaxation at regular intervals. ${ }^{45}$ One should be able in the meantime to see to one's other responsibilities as a spouse, father, mother and offspring, as the case may be. For these are likely to suffer in the event where a worker is exhausted and overtaken by fatigue. The Prophet has in yet another hadith warned against over-exertion, infliction of severity upon oneself, and indeed of developing such into a recurrent practice and expectation:

Do not be harsh with yourselves lest you be dealt with harshly, for some people were harsh with themselves, and Allah dealt with them harshly.

The renowned Ḥanafĩ jurist, Qāḍī Khān (d. 1195 CE), has recommended that a certain amount of the public treasury funds be allocated for the medical and welfare needs of workers. Since the workers' only asset that enables them to earn a living is their fitness and good health, and the community's welfare also depends on their wellbeing, their health is a joint responsibility of the employer and that state. ${ }^{46}$

The pattern of rest and recreation, according to fiqh rules, is to be determined by reference to the prevailing custom. Workers should be treated such that their productive energy remains a source of sustained benefit for themselves, their families and the community at large. Working hours and workload as well as the physical environment of work are among the factors that call for particular attention. These are also some of the conclusions contemporary writers and commentators on the subject have drawn from their reading of the basic data of Qur'ān and hadīth. ${ }^{47}$ The broad message of this evidence is conveyed in the Qur'ānic verse that "God intends for you facility and ease and He intends not to put you in hardship;" (al-Baqarah, 2:185) which is endorsed, in turn, in another verse that "God intends not to make religion a means of hardship upon you" (alHajj, 22:78, and al-Mā’idah, 5:6). 
Lastly, The 1989 Islamic Declaration of Human Rights, which has been ratified by member countries of the Organisation of Islamic Conference (now Cooperation) in its $17^{\text {th }}$ session in Tehran entitles every employee to break periods during the daily work hours, and periodical holidays during which the employee remains entitled to his or her normal emoluments. ${ }^{48}$

\section{Art and Music}

The overly restrictive view many Islamic religious scholars and others are inclined to take of music, art and entertainment needs to be moderated as it is not only unrealistic but also not quite in line with Islam's vision of itself as a comprehensive religion. For Islam pays attention to all aspects of human existence: physical, spiritual, intellectual and emotional, and seeks ways and means to fulfil them within the limits of moderation. If physical exercise and movement stimulate the body, if worship nourishes the soul, and knowledge nourishes the intellect, then music, art and entertainment nourish and moderate emotions. ${ }^{49}$ Art and music that elevate but not degrade the spirit bring beauty, which is an important part of Islam. This is because Jamil (beautiful) is one of Most Excellent Names (al-asmā'al-husnā) of God - He loves beauty and desires it so that everyone tries to bring it out in oneself and one's outside environment and living conditions. If art is all about beauty and positively contributes to emotional health, then that is precisely what Islam also desires in its followers. ${ }^{50}$ Islam's view of beauty, rhythm, and psychologically penetrating language is an integral part of what is known as imitability ( $\left.i^{\prime} j \bar{a} z\right)$ of the Qur'ān. Qur'ān reading (tilāwah) in musical rhythm and incantation (tajwìd) in human voice by renowned Qur'ān readers penetrate the senses and helps establish a closer identity with the Qur'ānic language and message. Islam promotes beauty - and art definitely manifests it in ways that words often fall short of doing. ${ }^{51} \mathrm{Al}$-Qaraḍāwī has quoted numerous verses from the Qur'ān where the text mentions beauty (zinah, husn, jamāl) frequently in God's creation, for instance, of the human person, whom He created and fashioned "in the best of forms;" the earth, the mountains and the skies that "He fashioned and beautified;" the animals in which there is "beauty and comfort;" and that "He beautified everything He has created." 52

There are certain things that no text and fatwa can regulate and moderate better than the person who actually experiences them. Singing, music, entertainment and the manner how excessive indulgence in them can be avoided in favour of beneficial enjoyment are perhaps among them. Singing is rhythmical speech and the good and bad in it depends on what it might be saying. One cannot denounce all singing just like one cannot denounce all speech, whether it is accompanied by musical sounds or not. Instruments have no intrinsic value of their own but the value in them can be ascertained by reference to the manner of their use, 
surrounding conditions and context. This is precisely what the Qur'ān also says about poetry: the good and the bad in it is to be determined by reference to what it says (al-Shu 'arā', 24:224-227). If songs and music are accompanied by drinking, gambling and promiscuity, these are prohibited and so will be the song and music that promote and encourage them, not the song or musical instrument as such..$^{53}$

There is general consensus among Muslim scholars on the permissibility of song and music that celebrate weddings, births, Eid festivals, safe return of travellers and the like. ${ }^{54}$ Some genres of song and poetry that praise God and pay tribute to Muhammad (known in Persian as munäjät and na'at respectively) partake in devotional remembrance (dhikr). This can also be said perhaps of some of the Sufi practices that are accompanied by incantations and devotional remembrance with or without music. Music and singing are permissible and moderation in them advised. For the good therein touches human consciousness and emotion with the essence of beauty.

Beauty and enjoyment can also be derived from intellectual nourishment and learning. To pay attention to one's intellectual and emotional wellbeing is a question to a large extent of finding a correct balance between them in the true meaning of moderation. ${ }^{55} \mathrm{Al}-\mathrm{Q}$ araḍāwi has subscribed to the permissibility of singing and music, however, with the following provisos:

- The contents do not violate Islamic principles.

- The style of singing and/or performing art is clear of both debasement and over-indulgence.

- The context and audience are dignified and clear of depraving and lascivious influences. ${ }^{56}$

\section{Islam's Model of a Moderate Personality}

Is there an Islamic model of personal conduct? Can one find in the sources of Islam an ideal character or attributes of character that in a positive sense offers an example to be emulated - one that could be said to epitomise the best of what Islam teaches on moderation? This may well be the Qur'ānic conception of halim - one who possesses the qualities of hilm (compassionate forbearance) to which a reference has already been made. Hilm is a comprehensive behavioural concept that combines many features, most of which relate closely to character and lifestyle, and merits some elaboration as follows.

In the Arabic dictionary, Täj al-'Arūs by al-Zabīdī, the word hilm is defined as 'the act of reining one's soul and holding back one's nature from the violent emotion of anger,' and in Muhị al-Muhị t by al-Bustānī as 'the state of the soul remaining tranquil, so that anger cannot move it easily.' Al-Bustānī adds to this the inclination of 'being slow in requiting the wrong-doer. ${ }^{57} \mathrm{In}$ its characteristic 
manifestations, hilm inclines toward gentleness, kindness and compassion that also integrate the ability to resist temptation to anger and provocation by the miscreant. A person who possesses the quality of hilm is likely to avoid conflict and seek instead peace and reconciliation. It is the quality which enables one to resist extremism, prejudice and injustice.

Halìm is one of the Excellent Names (al-asmā'al-husnā) of God. The Qur'ān also characterises the Prophet Muhammad as one who set a 'beautiful example' (uswah ḥasanah), (al-Aḥzāb, 33:21). For Muslims it is highly recommendable to make an effort to emulate his example. Then if one asks as to what precisely were the actual virtues that the Prophet integrated into his exemplary character - the answer we are given in the Qur'ān is almost invariably related to hilm, that is, gentleness, kindness and compassion. This is also how the Qur'ān characterised the patriarch Abraham almost singularly described by the attribute of hilm: "Surely Abraham was tender-hearted and compassionate - la-awwähun halim;" and again "Indeed Abraham was forbearing, tender-hearted and devout halìmun, awwāhun munīb" (Tawbah, 9:114; Hūd, 11:75).

Toshiko Izutsu writes, in a section of his book on identification of 'key Qur'ānic terms,' that it is not just the Prophet's character, but also that:

The Qur'ān as a whole 'is dominated by the very spirit of hilm. The constant exhortation to kindness (ị̣sān) in human relations, the emphasis laid on justice ( $\mathrm{adl}$ ), the forbidding of wrongful violence $(z u l m)$, the bidding of abstinence and control of passions, the criticism of groundless pride and arrogance - are all concrete manifestations of this spirit of hilm.58

Izutsu further observed that as a divine attribute, hilm is that particular kind of gentleness which emerges as the surface expression of underlying power: "God forgives sins committed by men and is [He is] gentle, but it is not a simple gentleness; it is gentleness based on power, forbearance based on calm wisdom, which is possible only because it is coupled with an infinite power." ${ }^{59}$ So if $a l$ Halim, on the divine level, is one whose gentle forbearance is based on infinite power, al-halim on the human level, describes one whose forbearance is based, not on infinite power, but on self-mastery and control. There is no power greater, on the human plane, than that required to dominate one's own ego and soul. ${ }^{60}$

Hilm is far from being a passive quality of simple patience and forbearance in the face of provocation, although it definitely comprises these virtues. Hilm must also be understood as "a positive and active power of the soul that is strong enough to curb her impetuosity... calm it down to patience and forbearance. It is a sign of the power and superiority of the mind." ${ }^{61} \mathrm{Hilm}$ is thus closely related to compassion and peace as well as the power necessary for self-control. Engaging oneself in excessive indulgence or extremism of any kind would be alien to hilm. 
Izutsu's analysis would be incomplete, however, without adding what he has to say about humility and kindness as salient components of Islamic ethics, and an aspect also of moderation:

Thus it comes about that the element of meekness, or humbleness, as the human counterpart of the benevolence of God, is made the very pivotal point of Islamic ethics. Most, though not all, of the recognised moral duties of Islam derive in fact from this pious benevolence. Kindness is enjoined upon the believers upon every possible occasion. Kindness should be the governing principle of all human relations in society as well as in family... ${ }^{62}$

\section{Conclusion and Recommendations}

This article reviewed the source evidence and scholarly heritage of Islam on moderation in the various spheres of the private and public lives of individuals and societies. The analysis it has advanced as a result sustains the following recommendations to government policy makers, NGOs, industrialists, public personalities and decision makers to:

- Reduce and minimise empty and misleading advertisements on television and in the mass media that promote excessive consumerism and unhealthy practices in food consumption patterns and life style.

- Promote and encourage healthy eating: less sugar, less fat and less red meat, for example. Provide information and advice on suitable alternatives.

- Educate the public on Islam's viewpoint and advice on moderation. Muslims have shown increased interest in religion on life style matters - Islamic scholars, personalities and Imams have a certain responsibility therefore to provide it.

- Reduce noise and uncomfortably high loudspeakers in densely populated areas on social and religious ceremonies and occasions. Science and technology experts, car and machinery manufacturers, sound equipment designers and others are also urged to make noise reduction and abatement an integral part of their production plans.

- Modesty, self-restraint and honesty in speech, social interaction and humour are central to the ethos of Islam. Muslims are advised therefore to integrate and encourage these values in their social relations and culture.

- Art, recreational entertainment and music that bring beauty and enjoyment without violating moral and religious principles should be encouraged and appreciated. 


\section{Notes}

* Mohammad Hashim Kamali, Founding Chairman and CEO of IAIS Malaysia, graduated from Kabul University, and took his PhD in Islamic and Middle Eastern Law at the University of London in 1969. Professor Dr M.H. Kamali served as Professor of Islamic Law and Jurisprudence at the International Islamic University Malaysia (IIUM, 1985-2007), then Dean of the International Institute of Islamic Thought and Civilization (ISTAC). He also held Visiting Professorships at McGill University's Institute of Islamic Studies; Capital University, Ohio; and the Wissenschaftskolleg, Berlin. A member of the Constitution Review Commission of Afghanistan (2003), he has provided expert legal consultation to the new constitutions of Iraq, the Maldives and Somalia. Eminent authority on Islamic legal studies, he has published over 150 academic articles and 35 texts, including standard textbooks at universities worldwide.

1. Kenneth Rogoff, "The costly issue of coronary capitalism," Kuala Lumpur: New Straits Times, February 7, 2012, p. 22.

2. Ibid.

3. Ibid.

4. Khoo Boo Teik and Tatsuya Tanami eds., Asia - Identity, Vision and Position, Asian Public Intellectuals Fellowships Program (The Nippon Foundation, 2012), 59.

5. Ibid., 60 .

6. Ibid., 61

7. Ibid.

8. Ibid., 60 .

9. A BBC report "Half of all food wasted," 10 January 2013, at http://www.bbc. co.uk/news/uk-20968808

10. Ibid.

11. Chok Suat Ling, "Malaysia has world eating out its hand," Kuala Lumpur: New Straits Times, 28 July 2012, 17.

12. Nurul Aziah Musa, "Lead up on superfoods," Kuala Lumpur: New Sunday Times, 19 February 2012, 17.

13. Ibn Qayyim al-Jawziyyah, Zad al-Ma'ad fi Huda Khayr al- 'Ibad, vol. 4. Beirut: Resalah Publisher, 2002, p. 16-18.

14. Agreed upon hadith (muttafaqun 'alayh) reported by all the major collections of hadith. See Abu Ibrahim 'Abd al-Wahid bin Yusuf al-Sharbini, al-Qasd wa'lWasatiyyah fi Daw' al-Sunnah al-Nabawiyyah, Riyadh: Maktabat al-Rushd, 1431/2010, 632, hadith no. 286.

15. Abul-Hussain 'Asakiruddin Muslim bin Hajjaj Al-Naisaburi, Mukhtasar Sahih Muslim: Kitab al-Salat. $6^{\text {th }}$ edition. Beirut: Maktab al-Islami, 1987. Edited by Al-Albani. n.d. See also for a slightly different version, Abu Ibrahim 'Abd alWahid bin Yusuf Al-Sharbini, Al-Qasd wa'l- Wasatiyyah fi Daw' al-Sunnah alNabawiyyah, Riyadh: Maktabat al-Rushd, 1431/2010, 632.

16. Al-Sharbini, al-Qașd wa'l-Wasatiyyah, 632.

17. Muslim, Mukhtașar Șahịh Muslim, ed. Al-Albani, p.147, hadìth no. 540.

18. Cf., al-Sharbini, al-Qasd wa'l-Wasatiyyah, 635.

19. Ibid. 
20. This is, however, not so for the Shi' is, who actually recommended fasting on the day of 'Ashūrā. 'Ashūrā had been considered by early Muslims to be a very auspicious and joyous day, as many important and happy events, such as the landing of Noah's Ark, took place on it. This perception of 'Ashūrā seems to have changed completely with the tragic death of the beloved grandson of the Prophet, Husayn - hence for the Sunnis too it became an event combining joy and tragedy together. See for details ed. John L. Esposito, The Oxford Encyclopedia of the Muslim World, 1995, Vol. 1, at 141.

21. Al-Sharbini, al-Qasd wa'l-Wasatiyyah, 638.

22. Mohamed Mukhtar Ahmad, "Month of spiritual overhaul," Kuala Lumpur: New Straits Times, August 10, 212, p. 18.

23. Shahid Athar, Medical Benefits of Ramadan, http://www.iol.ie/ afifi/BICNews/ Personal/personal24.htm

24. Letter (anonymous) to the Editor, "Be a responsible consumer," Kuala Lumpur: New Straits Times, June 23, 2012, p.4.

25. Ibid.

26. A. Kathirasen, "Take heed, drop meat," Kuala Lumpur: New Straits Times, September 6, 2012, p.17.

27. Ibid.

28. Muhiy al-Din al-Nawawi, Riyād al-Säliḥin, ed. Muhammad Nasir al-Din alAlbani, $2^{\text {nd }}$ ed., Beirut: Dar al-Maktab al-Islami, 1404/1984, p. 284, hadith no. 699.

29. Muslim, Mukhtasar Sahih Muslim, p. 218, hadìth no. 244.

30. 'Abd Allah al-Khatib Al-Tabrizi, Mishkat al-Masabih, ed. Mouhammad Nasir al-Din al-Albani, Beirut: al-Maktab al-Islami, 1399/1979, $2^{\text {nd }}$ ed., Vol.3, hadìth no. 4839.

31. 'Izz al-Dīn 'Abd al-Salām, al-Qawā'id al-Kubrā also known as Qawā'id alAhkām fi Masālih̆ al-Anām, Vol. 2. Edited by Nazizh Hammad, Damascus: Dar al-Qalam. 2010/1431, 347. 'Izz al-Dīn further adds: Muslim in his Sahih Muslim records many hadìths in his chapter on remembrance and supplication (fi'l-Dhikr $\left.w a^{\prime} l-D u^{\prime} \bar{a}^{\prime}\right)$ to the effect that it is a sign of gentleness to oneself and to others for one to speak in a soft voice. If this is in the context of worship then God the Most High is always present, the best Hearer and always close to one. In speaking to others one may speak loud if the audience is at a distance.

32. Ibid., Vol. 2, 343.

33. Cf., al-Sharbini, al-Qasd wa'l-Wasatiyyah, 611-612.

34. Abu Dawud, Sunan Abū Dawūd: Kitab al-Adab Bāb 'man ya'khuz al-shay' 'al al-mazah'. Vol 7. Damascus: Risalah al-Alamiah, 2009/1430, also recorded in 'Izz al-Dīn 'Abd al-Salām, Qawa'id, vol. 2, 348.

35. Shamsuddin 'Abd Allah Al-Maqdisi, al-Adab al-Shar'iyyah wa'l-Minah alMar'iyah, Cairo: Matba'at al-Manar, 1943/1348, vol. I, 21. This hadith also appears in the Musnad of Imam b. Hanbal.

36. Al-Bukhari, Abu Abdullah Muhammad ibn Ismail ibn al-Mughirah ibn Bardizbah, Sahih al-Bukhari: Kitab al-Adab 'Bab Ma Yunda'an al-Tahasud wa'l Tadabur. Beirut: Darul Fikr, 2005/1426.

37. Cf., al-Sharbini, al-Qasd wa'l-Wasatiyyah, 567-570.

38. As quoted in Al-Farfūr, Muhammad 'Abd al-Lațîf. Al-Wasatiyyah fì'l-Islām. 
Amman: Dār al-Nafā'is, 1988, 56: the quote in Arabic reads: "la yakun hubbuka kalafan owa la bughduka talafan."

39. Al-Sharbini, al-Qasd wa'l-Wasatiyyah, 571.

40. See survey report in Chok Suat Ling (New Sunday Times Editor), "Work to live not live to work," Kuala Lumpur: New Straits Times, 2 January 2014, 14.

41. Ibid.

42. Ibid.

43. Jalal al-Din al-Suyuti, al-Jami'al-Saghir, Vol. II, hadith no: 5585, 139.

44. Ibid., Vol. I, $202 \& 603$.

45. Al-Nawawi, Riyāẹ al-Sälihìn, hadith no. 153.

46. Cf., Fatāwà Qā $\bar{d} \bar{\imath}$ Khàn on the margin of al-Fatawa al-Hindiyyah, Vol. II, 314; also discussed by 'Abd al-Wahhab al-Shishani, Huquq al-Insan, 476.

47. Abu Daud al-Sijistani, Sunan Abi Daud, translated from Arabic by Nasiruddin Khattab, Riyadh: Darussalam, 2008, vol. 5, p. 314. Hadith no. 4904.

48. The Arabic title is al-I'lan al-'Alami li-Huquq al-Insan (Art. 24). The original Arabic text of this document appears in Appendix to Muhammad al-Zuhaily, Huquq al-Insan fi'l-Islam, 400-409 in (25) Articles.

49. Yusuf al-Qaradawi, al-Islam wa'l-Fann, $5^{\text {th }}$ ed., Cairo: Maktabah Wahbah, 2012/1433, p.13. See also Shaykh Akram Kassab, Dawr al-Qaradawi fi Ta'sil al-Wasatiyyah wa Ibraz Mualimiha. Cairo: Maktabah Wahbah, 2008/1429, 132 quoting al-Qaradawi's book Fiqh al-Ghana wa'l-Mosiqi, 18-19.

50. Ibid., 14.

51. Kassab, Dawr al-Qaradawi, 134.

52. Qur'an al-Taghabun, 64:3; Qaaf, 50:6 \& 7; al-Nahl, 16:5; and al-Sajdah, 32:7 respectively.

53. Qaradawi, al-Islam wa'l-Fann, 30-32.

54. Ibid., 32 .

55. Cf., ibid., 11.

56. Al-Qaradawi as quoted in Kassab, Dawr al-Qaradawi, 134.

57. Al-Zabīdī, Tāj al-'Arūs under Hilm, 335f, and al-Bustānī, Muhìt al-Muhìt at 443 - both as quoted by Toshiko Izutsu, Ethico-Religious Concepts in the Qur'an, 1971. Reprint. Kuala Lumpur: Islamic Book Trust, 2004, pp. 31-32.

58. Izutsu, God and Man in the Qur'an, 1964. Reprint. Kuala Lumpur: Islamic Book Trust, 2008, p. 236.

59. Ibid., 227-228.

60. Cf., Shah-Kazemi, The Spirit of Tolerance in Islam. Occasional Paper 5, London: I.B. Tauris, 2012, 116-117.

61. Izutsu, God and Man, 226.

62. Izutsu, Ethico-Religious Concepts, 73. 